\title{
Seedbank diversity in grazing lands of the Northeast United States
}

\author{
BENJAMIN F. TRACY AND MATT A. SANDERSON
}

Authors are Postdoctoral Research Associate and Research Agronomist, USDA Agricultural Research Service, Pasture Systems and Watershed Management Research Lab, Curtin Rd., University Park, Penn. 16802.

\begin{abstract}
We evaluated the species composition of soil seed banks from 9 farms (36 pastures total) located in the northeast United States. Our objective was to quantify the soil seed bank composition of pastures managed for intensive grazing and hay production. Seeds from pasture soils were allowed to germinate in a greenhouse under natural light conditions. Seedlings were identified as they germinated, and the experiment was concluded after 4 months. Germinable seed was dominated by annual $(40 \%)$ and perennial $(\mathbf{2 3} \%)$ forbs most of which contributed little useful forage for cattle. Perennial grasses (11\%), except for bluegrass (Poa pratensis $\mathbf{L}$.), were largely absent from the germinable seed bank, while legumes (19\%) were more abundant. Seed bank species composition showed little similarity $(44 \%)$ to the existing vegetation. Exceptions were bluegrass, white clover (Trifolium repens L.), and common dandelion (Taraxacum officinale Weber ex Wiggers). These species were abundant in both the germinable seed bank and existing vegetation on most pastures. Overall, our study suggests that seed banks in these northeast pastures support abundant white clover and bluegrass seed, both of which are important forages for cattle. Soil seed banks, however, will not supply a diverse assemblage of useful forages. If a manager seeks to establish diverse, mixed-species pasture, then re-seeding pastures with desired mixes may be the best option.
\end{abstract}

Key Words: management-intensive grazing, viable seed, aboveground vegetation, temperate grasslands

The species composition of buried seed in a plant community depends on seed inputs from present and previous vegetation and the longevity of viable seed under local conditions (Roberts 1981). Knowledge of this seed bank is essential to achieve a more complete understanding of local vegetation dynamics, since composition of the soil seed bank may predict what species dominate a plant community after disturbance (Nobel and Slatyer 1980). If a land manager wishes to promote recruitment of desirable species from existing seed banks, then it is first crucial to determine its composition. Although not often used in terrestrial plant communities, seed-bank resources can be effectively managed to recruit useful plants into the community. Successful management based on seed bank exploitation requires 3 conditions be met: 1) seeds of desirable species are present in the soil, 2) seeds of unde-

Authors wish to thank G. McGee, H. Pionke and B. Wilsey for helpful comments on earlier drafts.

Manuscript accepted 13 Mar. 1999.

\section{Resumen}

Evaluamos la composición de especies del banco de semillas del suelo de 9 granjas (36 potreros en total) localizadas en el noreste de Estados Unidos. Nuestro objetivo fue cuantificar la composición del banco de semillas del suelo de potreros manejados con apacentamiento intensivo y producción de heno. Las semillas de los potreros se germinaron en invernadero bajo condiciones de luz natural. Las plántulas se identificaron conforme germinaron y el experimento terminó en 4 meses. La semilla que germinó estuvo dominada por hierbas anuales $(40 \%)$ y hierbas perennes $(23 \%)$, muchas de las cuales contribuyen con poco forraje útil para el ganado. Los zacates perennes $(11 \%)$, excepto "Bluegrass" (Poa pratensis L.), estuvieron ausentes en el banco de semilla, mientras las leguminosas (19\%) fueron más abundantes. La composición de especies del banco de semillas mostró poca similitud $(44 \%)$ con la vegetación existente. Las excepciones fueron "Bluegrass", "White clover" (Trifolium repens L.) y "Common dendelion" (Taraxacum officinale Weber ex Wiggers). Estas especies abundaron tanto en el banco de semillas germinables como en la vegetación existente en el potrero. En general, nuestro estudio sugiere que los bancos de semilla en estos potreros del noreste poseen abundante semilla de "white clover" y "Bluegrass", las cuales son especies importantes para el ganado. Sin embargo, los bancos de semilla no suministran un ensamble diverso de especies forrajeras útiles. Si el manejador busca establecer un potrero con diversas especies, entonces la resiembra de potreros con mezclas de especies deseables puede ser la mejor opción.

sirable species are rare and 3) conditions are suitable for germination and establishment of preferred species (van der Valk and Pederson 1989).

Pasture represents approximately $8 \%$ ( $\sim 3.5$ million hectares) of the non federal, rural land use in the 12 state region of the northeast with crop land and forest occupying significantly more (USDA 1994). Although some work has evaluated seed bank composition of abandoned agricultural fields in the northeast US (Leck and Leck 1998), little recent research has assessed seed bank resources of pasture lands in this region. Prince and Hodgdon (1946) studied seed bank species composition in 21 New Hampshire pastures, but no work has been published since then.

The objective of this study was to quantify the soil seed bank composition of pastures managed for intensive grazing and hay production across the northeast US. The focus of the survey was to determine the relative abundance of useful forage species for cattle and hay production (e.g. perennial grasses and legumes) 
present in the seed bank and relate the composition of the seed bank to existing vegetation on these pastures.

\section{Material sand Methods}

A total of 36 pastures from 9 farms were sampled in this study. Four farms were located in New York, 4 in Vermont and 1 in Pennsylvania. These farms lie in the region between 40 and $45^{\circ} \mathrm{N}$ and 72 and $77^{\circ} \mathrm{W}$ in the northeast United States. This is a cool, humid region of plateaus, plains, and mountains. Average annual temperatures in this region range from $4-13^{\circ} \mathrm{C}$, with average annual precipitation ranging from 750-1,325 $\mathrm{mm}$ (USDA 1981). In most of the region, one half of the precipitation falls in the freeze-free season, which ranges from 110-170 days (USDA 1981). Soils in the study region are dominated by Ochrepts, Orthods and Aqualfs (USDA 1981). Farms were selected because they either relied on management-intensive grazing (MIG) to supply feed for cattle or were about to be converted to managementintensive grazing (MIG). Managementintensive grazing is characterized by applying a high stocking density to a small paddock $\left(0.5^{-1} \mathrm{ha}\right)$ for a short $(12-48 \mathrm{hr})$ period then moving cattle to fresh pasture. Seven of the 9 farms were dairy operations that relied on management-intensive grazing as the primary feed for cattle. Although these pastures were primarily managed for grazing, farmers also took 1 or 2 cuttings of hay from these pastures each year. Two farms had not been grazed in the last 5 years but were about to be converted to MIG systems. These 2 farms were sporadically used for hay production, however, so old field succession to woodland was not allowed to progress during the years pastures were not grazed. One of these had been plowed and left fallow for several months before sampling. To our knowledge, none of the pastures had been seeded within the last 5 years.

We randomly selected four pastures on each farm for sampling. Pasture size varied from 2-10 ha with a median of 4 ha. Sampling occurred in July and August 1997. Vegetation composition was assessed by noting the species present in 15 , randomly positioned $1 \mathrm{~m}^{2}$ quadrats. Five soil cores were taken from random locations in each pasture for subsequent seed bank analyses. Cores were $10 \mathrm{~cm}$ in diameter and taken to a $10 \mathrm{~cm}$ depth.

Soil cores were stored in a dark freezer $\left(\sim 0{ }^{\circ} \mathrm{C}\right)$ for 3 months. Cores were then air dried at $20^{\circ} \mathrm{C}$ and sieved ( $1 \mathrm{dm}$ mesh) to remove large rocks and roots. Soil from the 5 cores from each pasture were pooled and spread into plastic trays ( 25 by 50 by $6 \mathrm{~cm}$ ) to a depth of $2 \mathrm{~cm}$ over $2 \mathrm{~cm}$ of sterile potting soil. Trays were placed in a greenhouse (temperature $18 \pm 4^{\circ} \mathrm{C}$ ) and allowed to germinate under natural light conditions. Soils were watered once or twice daily with tap water. As seedlings germinated they were identified and removed from trays. Seedlings that could not be identified were transplated to pots. Soils in each tray were mixed regularly with a small trowel to increase germination. Germination trials lasted approximately 4 months (15 December 1997- 16 April 1998).

The relative frequency of plant species in aboveground vegetation was compared to germinable seed using linear regression. The number of plant species (species richness $S$ ) was calculated for each pasture. Sorensenís coefficient of community (CC) (Magurran 1988) was calculated to index similarities between the seed bank and vegetation.

$$
\mathrm{CC}=2(\mathrm{c}) / \mathrm{s} 1+\mathrm{s} 2
$$

Where (c) is the number of species common to both seed bank and vegetation and (s1) and (s2) are the respective number of species detected in the plant community and its associated seed bank. Farms were considered the experimental unit and ttests were used to compare variables between the grazed $(n=7)$ and hayed farms $(n=2)$. We considered $\mathrm{p}<0.10$ as statistically significant.

\section{Results}

Aboveground vegetation cover on most farms was dominated by bluegrass (Poa pratensis L.), white clover (Trifolium repens L.) and common dandelion Mean species richness $(S)$ in vegetation and seedbank for 9 farms where pastures were either hayed or intensively grazed. Farms were sampled across the northeast US in July and August 1997. Values are means with 1 SE () calculated from 4 pastures on each farm $(n=4)$.

\begin{tabular}{llcc}
\hline \hline \multirow{2}{*}{ Farm } & & \multicolumn{2}{c}{ Species Richness (S) } \\
\cline { 3 - 4 } Hayed Pastures & & Vegetation & Seedbank \\
& 1 & $13(1)$ & $18(1)$ \\
Grazed Pastures & 2 & $15(2)$ & $15(3)$ \\
& 3 & $11(1)$ & $12(1)$ \\
& 4 & $10(0)$ & $7(1)$ \\
& 5 & $11(1)$ & $8(0)$ \\
& 6 & $12(1)$ & $10(3)$ \\
& 7 & $18(3)$ & $10(1)$ \\
& 8 & $14(1)$ & $6(1)$ \\
9 & $15(2)$ & $4(1)$ \\
\hline
\end{tabular}

(Taraxacum officinale Weber ex Wiggers). Orchard grass (Dactylis glomer ata L.) and English plantain (Plantago lanceolata L.) were also abundant on many of the pastures. A total of 54 species germinated from soil seed banks of the nine farms. Across farms, the number of species in the germinated seed ranged from 4 to 18 , while mean species richness of vegetation ranged from 10-18 (Table 1). Overall, the number of species in seed banks was unrelated to the number of species in existing vegetation (linear regression, $r=0.14, p>0.10$ ). Pastures on farms that had not been grazed in the last 5 years (Farms 1 and 2) contained more species in their seed banks than pastures that had been in continuous grazing $(\mathrm{t}=$ $3.92, \mathrm{p}=0.005, \mathrm{df}=7$ ).

Annual and perennial forbs constituted more than $50 \%$ of the seed bank species composition on 8 of 9 farms (Fig. 1a). On farm 9, the seed bank was primarily white clover, a legume (Fig. 1b). Annual forbs made up a greater proportion of the seed bank from ungrazed farms than grazed farms $(t=3.21, p=0.01, d f=7)$. Functional groups important for cattle forage, perennial grasses and legumes, accounted for less than $50 \%$ of the seed bank species composition on 8 of 9 farms. More perennial grasses germinated from soils taken on ungrazed farms compared with grazed farms $(\mathrm{t}=2.16, \mathrm{p}=0.06, \mathrm{df}=7)$. While not statistically significant, legumes were generally more abundant in cores taken from grazed farms (Fig. 1b). On farm 7, only $3 \%$ of the germinable seed was white clover. This low value primarily accounted for the lack of statistical difference between legume density on grazed and ungrazed farms. Seedlings of annual grasses were abundant on only 2 farms (\# 2 and 6) (Table 2).

Four species were common to the seed banks of all nine farms: white clover, yel- 

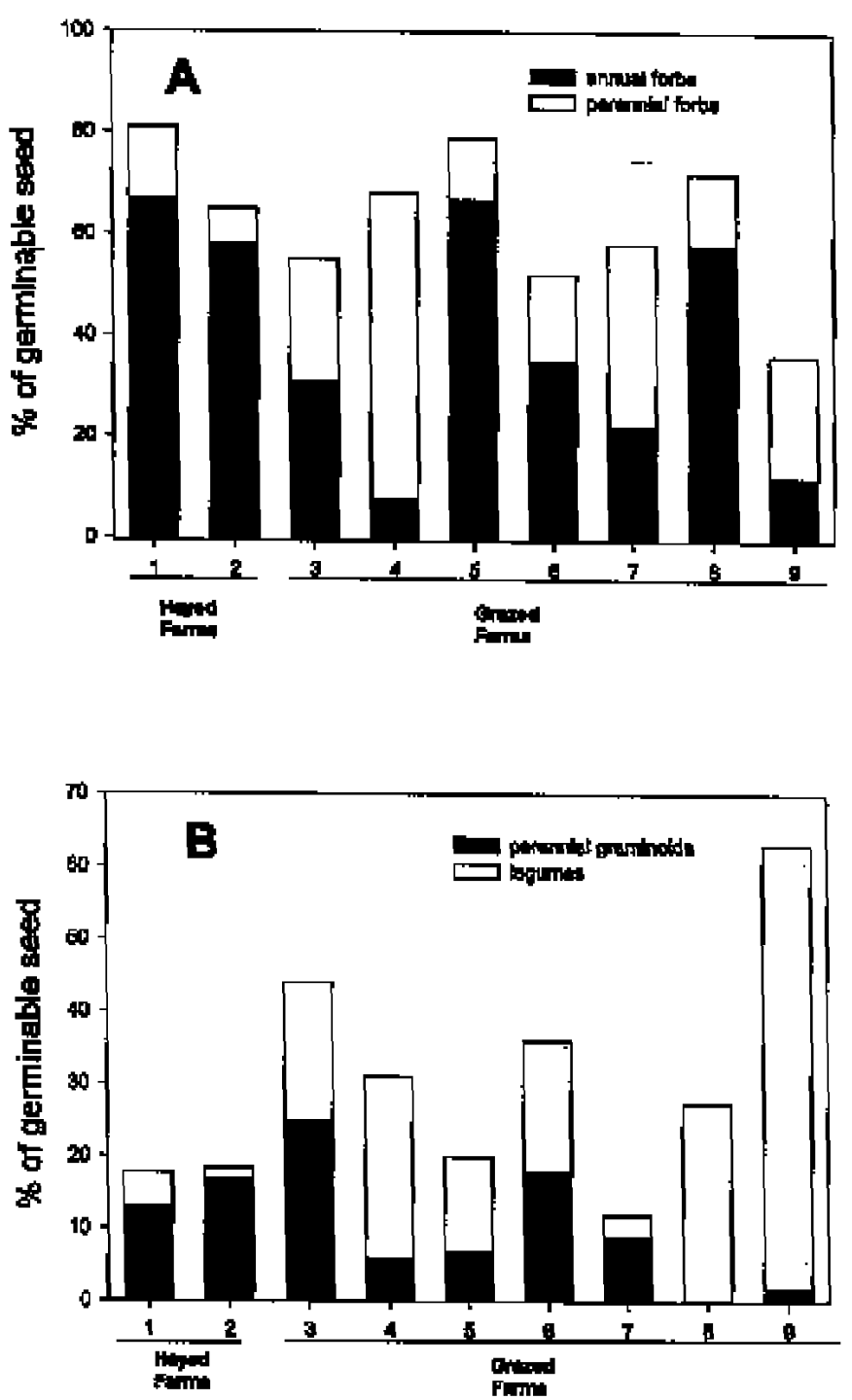

Fig. 1. Percent of the total germinable seed that were (A) annual and perennial forbs and (B) perennial grasses and legumes. Farms 1 and 2 were hayed in the last five years while farms 3-9 were in continuous rotational grazing.

low wood sorrel (Oxalis stricta L.), common dandelion and bluegrass (Table 2). Among the annual forbs, yellow rocket (Barbarea vulgaris R. Br.) and lamb's quarters (Chenopodium album L.) attained the highest densities on 7 of the 9 farms. Among annual grasses, yellow foxtail (Setaria glauca P. Beauv.) yielded the highest density of seedlings, but it was only found on 2 farms. Chess grass (Bromus secalinus L.) was more common across farms. Seedlings of white clover, dandelion, and bluegrass were the most abundant legume, perennial forb and perennial grass, respectively.

Sorensen's coefficient of community (CC) was calculated to index similarities between seed bank and vegetation species on respective farms (Fig. 2). Seed bank species and existing vegetation were more

\section{Discussion}

Our findings suggest that seed banks in northeast pastures may not supply a diverse assemblage of useful forage species for cattle. With the exception of bluegrass, perennial grasses, were essentially absent from the germinable seed bank. Prince and Hodgdon (1946) also found abundant germination of bluegrass, and detected few economically useful species in their survey of 21 pastures in New Hampshire. Although dominant in the vegetation, perennial grasses are almost universally under represented in the germinable seed bank (Chippindale and Milton 1934, Prince and Hodgdon 1946, Champness and Morris 1948, Major and Pyott 1966, Archibold 1981, Rabinowitz 1981, Hassan and West 1986, Rice 1989, Perez et al. 1998). Unlike annual and perennial forbs, most perennial grasses rely on vegetative reproduction and have not evolved seed that remains viable for long periods in soil (Roberts 1981). Unless germination conditions are immediately optimal for perennial grasses, much of this seed will be lost from the seed bank through decomposition or predation. Bluegrass is an exception to most perennial grasses because it forms substantial reserves of viable seed (Chippindale and Milton 1934, Champness and Morris 1948, Jalloq 1975, Roberts 1981). Of course, grazing can also affect seed bank composition (Major and Pyott 1966, Jalloq 1975, Iverson and Wali 1982, Kinucan and Smeins 1992, Bertiller 1992) especially if defoliation interrupts sexual reproduction.

Legumes were more abundant than perennial grasses in seed banks, particularly on farms that used management-intensive grazing. Compared with most perennial grasses, legumes produce large numbers of durable seed that maintain viability for long periods (Beale 1974, Jalloq 1975, Jones and Evans 1977, Rice 1989). Furthermore, some legumes like white clover have no specific germination requirements, so their seeds may germinate readily under many different conditions particularly if the population has a low abundance of hard seed genotypes (Turkington and Burdon 1983). Grazing by cattle may also increase seed production of white clover and indirectly raise seed bank stores. Because grazing reduces the height of tall grasses and increases light availability for more prostrate white clover plants, grazing may indirectly promote clover growth and reproduction. 
Table 2. Mean density of germinated seedlings $\left(\mathrm{m}^{-2}\right)$ for the 9 farms surveyed and the number of farms where the respective species were found. Values are means and $1 \mathrm{SE}$ from the 9 farms. Nomenclature follows (Gleason and Cronquist 1991).

\begin{tabular}{|c|c|c|c|c|c|c|c|}
\hline & Mean & $\mathrm{SE}$ & \# of farms & & Mean & $\mathrm{SE}$ & \# of farms \\
\hline & $\left(\mathrm{m}^{-2}\right)$ & & & & $\left(\mathrm{m}^{-2}\right)$ & & \\
\hline Annual/Biennial Forbs & 1019 & 386 & 9 & Legumes & 224 & 51 & 9 \\
\hline Abutilon theophrasti & 75 & 29 & 3 & Baptista tinctoria & 6 & & 1 \\
\hline Amaranthus blitoides & 9 & 1 & 3 & Medicago lupulina & 33 & 18 & 6 \\
\hline Amaranthus retroflexus & 6 & 0 & 2 & Trifolium pratense & 6 & & 1 \\
\hline Ambrosia artemisiifolia & 22 & 3 & 4 & Trifolium repens & 201 & 48 & 9 \\
\hline Anthemis arvensis & 35 & 19 & 4 & & & & \\
\hline Arabis lyrata & 64 & & 1 & Perennial Forbs & 330 & 47 & 9 \\
\hline Barbarea vulgaris & 462 & 192 & 7 & Allium canadense & 13 & & 1 \\
\hline Brassica kaber & 241 & 136 & 3 & Cerastium vulgatum & 39 & 12 & 8 \\
\hline Capsella bursa-pastoris & 96 & 34 & 6 & Cichorium intybus & 26 & & 1 \\
\hline Cardamine hirsuta & 19 & & 1 & Glechoma hederacea & 13 & & 1 \\
\hline Cardamine parviflora & 13 & & 1 & Oxalis stricta & 56 & 15 & 9 \\
\hline Chenopodium album & 319 & 122 & 7 & Plantago major & 78 & 21 & 6 \\
\hline Cirsium vulgare & 6 & & 1 & Potentilla norvegica & 21 & 6 & 6 \\
\hline Daucus carota & 34 & 13 & 2 & Rubus spp. & 6 & 0 & 2 \\
\hline Erigeron annuus & 19 & 0 & 2 & Rumex crispus & 49 & 17 & 2 \\
\hline Erysimum cheiranthoides & 13 & & 1 & Taraxacum officinale & 150 & 39 & 9 \\
\hline Euphorbia nutans & 32 & 6 & 2 & Veronica serpyllifolia & 15 & 3 & 3 \\
\hline Malva neglecta & 13 & & 1 & & & & \\
\hline Oenothera biennis & 64 & 17 & 3 & Perennial Grasses & 292 & 122 & 9 \\
\hline Polygonum aviculare & 28 & 3 & 3 & Cyperus spp. & 16 & 5 & 2 \\
\hline Polygonum convolvulus & 6 & & 1 & Dactylis glomerata & 26 & 7 & 3 \\
\hline Polygonum pensylvanicum & 21 & 4 & 3 & Elytrigia repens & 19 & 3 & 2 \\
\hline Sonchus asper & 38 & 15 & 2 & Festuca arundinacea & 10 & & 1 \\
\hline Stellaria media & 77 & 38 & 6 & Juncus tenuis & 53 & & 1 \\
\hline Urtica dioica & 33 & 9 & 5 & Phalaris arundinacea & 37 & 11 & 4 \\
\hline Veronica arvensis & 41 & 13 & 2 & Poa pratensis & 252 & 118 & 9 \\
\hline Veronica peregrina & 483 & & 1 & & & & \\
\hline Annual Grasses & 273 & 147 & 5 & & & & \\
\hline Bromus secalinus & 8 & 1 & 4 & & & & \\
\hline Echinochloa crusgalli & 58 & & 1 & & & & \\
\hline Panicum dichotomiflorum & 10 & 2 & 2 & & & & \\
\hline Роа аппиа & 269 & & 1 & & & & \\
\hline Setaria glauca & 494 & 221 & 2 & & & & \\
\hline
\end{tabular}

Most studies report striking differences between the species composition of grassland seed banks and standing vegetation (Major and Pyott 1966, Rabinowitz 1981, Hassan and West 1986, Bertiller 1992, Kinucan and Smeins 1992). In our survey, several species, (e.g. yellow rocket, lamb's quarters and chick weed) were abundant in the seed bank but rare in the vegetation. Such species likely represent past ecological conditions, have pulsed seed input, possess long-lived seed, and may only emerge from the seed bank under specific conditions (Rabinowitz 1981). These species probably become more important in the community after severe disturbance, and their identification in the seed bank may be important to predict vegetation dynamics in these pastures.

Positive correlations between seed bank species composition and the composition of aboveground vegetation suggests that either a large proportion of the seed recently entered the seed bank or, in the case of a more persistent seed bank, species abundance in the seed bank is more continuous where it is present in the vegetation (Kirkham and Kent 1997). Bluegrass, white clover, and dandelion were abundant in both the germinable seed

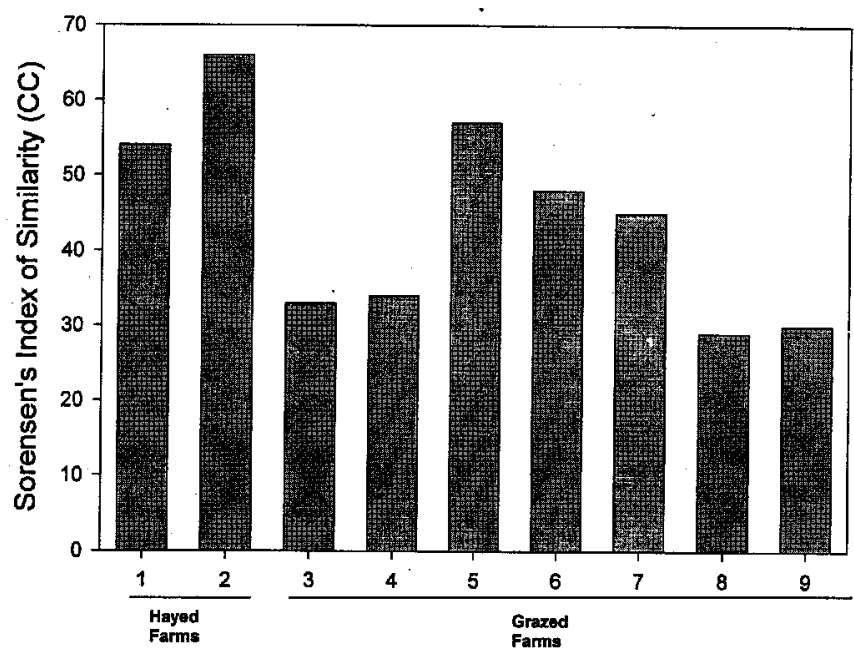

Fig. 2. Sorensen's index for community similarity (Magurran 1988) comparing seed bank species and standing crop in pastures. Higher values indicate greater similarity between the germinable seed bank and existing vegetation. 
ment of seed bank individuals. Although dandelion was abundant in both the seed bank and vegetation on most farms, this species does not produce seed that remains viable in the soil for long periods (Grime et al. 1988). The abundance of dandelion in the germinable seed bank likely reflects recent seed input during the spring before soil cores were collected (August). To reduce dandelion abundance, eradication measures should be applied early in the spring before most individuals set seed.

In our study, ungrazed pastures showed higher similarity in species composition between their seed bank and aboveground vegetation than did grazed pastures, especially for annual and perennial forbs. In general though, our findings differ from those of Kinucan and Smeins (1992) who found weedy dicots more prevalent in the seed banks of grazed areas compared with ungrazed areas. Possibly, grazing intensity was lower on our pastures and thus did not promote extensive recruitment of weedy species from the seed bank. A better explanation is that annual forbs were competitively excluded by either bluegrass, white clover or dandelion that became established in gaps created by grazing. Our data suggests that existing seed banks or inputs from seed rain can supply these species to fill gaps created in the grassland canopy. Other than white clover, however, we find no evidence that grazing increases the density of desirable forage species in seed banks.

\section{Conclusions}

Findings from this study showed that seed banks from northeast pastures contain an abundance of viable bluegrass and white clover seed, but few other useful forage species. Frequent recruitment of bluegrass and white clover seedlings into the aboveground vegetation probably helps maintain a stable forage base in response to frequent disturbance in these pastures. Nevertheless, more research is needed to develop management strategies or new seed types that will increase the diversity of viable forage seed in pastures. A diverse and viable seed bank of forages may allow farmers to depend less on replanting or frequently over seeding pastures to attain desired pasture mixes for specific operational needs.

\section{Literature Cited}

Archibold, O. W. 1981. Buried viable propag ules in native prairie and adjacent agricultural sites in central Saskatchewan. Can. J. Bot. 59:701-706.
Beale, P. E. 1974. Regeneration of Trifolium subterraneum $\mathrm{cv}$. yarloop from seed reserves in soil on Kangaroo Island. J. Aust. Inst. Ag. Sci. 40: 78-80.

Bertiller, M. B. 1992. Seasonal variation in the seed bank of a Patagonian grassland in relation to grazing and topography. J. Veg. Sci. 3:47-54.

Champness, S. S. and K. Morris. 1948. The population of buried viable seeds in relation to contrasting pasture and soil types. J. Ecol. 36:149-173.

Chippindale, H. G. and W. E. J. Milton. 1934. On the viable seeds present in the soil beneath pastures. J. Ecol. 22:508-531.

Gleason, H. A., and A. Cronquist. 1991. Manual of Vascular Plants of the Northeastern United States and Adjacent Canada. 2nd Edition. The New York Botanical Garden, Bronx, N.Y.

Grime, J. P., J. G. Hodgson, and R. Hunt. 1988. Comparative Plant Ecology: a Functional Approach to Common British Species. Unwin Hyman, London.

Hassan, M. A. and N. E. West. 1986. Dynamics of soil seed pools in burned and unburned sagebrush semi-deserts. Ecol. 67: 269-272.

Iverson, L. R. and M. K. Wali. 1982. Buried, viable seeds and their relation to revegetation after surface mining. J. Range Manage. 35: 648-652.

Jalloq, M. C. 1975. The invasion of molehills by weeds as a possible factor in the degeneration of reseeded pasture. J. Appl. Ecol. 12: 643-657.

Jones, R. M. and T. R. Evans. 1977. Soil seed levels of Lotonis bainesii, Desmodium intor tum, and Trifolium repens in subtropical pastures. J. Aust. Inst. Agr. Sci. 43:164-166.

Kinucan, R. J. and F. E. Smeins. 1992. Soil seed bank of a semiarid Texas grassland under three long - term (36 years) grazing regimes. Amer. Mid. Nat.128:11-21.

Kirkham, F. W. and M. Kent. 1997. Soil seed bank composition in relation to the aboveground vegetation in fertilized and unfertilized hay meadows on a Somerset peat moor. J. Appl. Ecol. 34:889-902.

Leck, M. A. and C. F. Leck. 1998. A ten-year seed bank study of old field succession in central New Jersey. J. Torr. Bot. Soc. 125: $11-32$.

Magurran, A. E. 1988. Ecological Diversity and its Measurement. Princeton University Press, Princeton, N.J.

Major, J. and W. T. Pyott. 1966. Buried, viable seeds in two California bunchgrass sites and their bearing on the definition of a flora. Vegetatio 13:253-282.

Nobel, I. R. and R. O. Slatyer. 1980. The use of vital attributes to predict successional changes in plant communities subject to recurrent disturbances. Vegetatio. 43:5-21.

Perez, C. J., S. S. Waller, L. E. Moser, J. L. Stubbendieck, and A. A. Steuter. 1998. Seed bank characteristics of a Nebraska sandhills prairie. J. Range Manage. 51:55-62.
Prince, F.S. and A.R. Hodgdon. 1946. Viable seeds in old pasture soils. N.H. Agr. Exp. Sta. Tech. Bull. 3-16

Rabinowitz, D. 1981. Buried viable seeds in a North American tall-grass prairie: the resemblance of their abundance and composition to dispersing seeds. Oikos 36:191-195.

Rice, K. J. 1989. Impacts of seed banks on grassland community structure and population dynamics. p. 211-229. In: M. A. Leck, V. T. Parker, and R. L. Simpson, (eds.) Ecology of Seed Banks. Academic Press, San Diego, Calif.

Roberts, H.A. 1981. Seed banks in soils. Adv. Appl. Biol. 6:1-45.

Turkington, R. and J. J. Burdon. 1983. The biology of Canadian weeds. 57. Trifolium repens L. Can. J. Plant Sci. 63:243-266.

US Department of Agriculture Soil Conservation Service. 1981. Land resource regions and major land resource areas of the United States. Agr. Handb. 296. Washington, D.C.

US Department of Agriculture Soil Conservation Service. 1994. Summary Report 1992 National Resources Inventory, Washington, DC.

van der Valk, A.G. and R. L. Pederson. 1989. Seed banks and the management and restoration of natural vegetation. p. 329-344. In: M. A. Leck, V. T. Parker, and R. L. Simpson (eds.) Ecology of Soil Seed Banks. Academic Press, San Diego, Calif. 